\title{
Peertechz
}

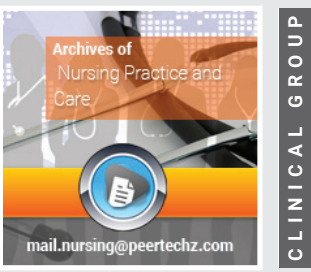

\section{Outbreak \& Early Situation of Coronavirus Disease 2019 (COVID-19) in Pakistan}

\section{Safiullah Khan Achakzai ${ }^{1}$, Anwer Bugti ${ }^{2}$, Abdul Samad ${ }^{1}$, Jawad Ahmed Khan ${ }^{2}$, Asad Khan ${ }^{3 *}$, Farmanullah ${ }^{3}$ and Naveed UI $\mathrm{Haq}^{3}$}

${ }^{1}$ Center for Advanced Studies in Vaccinology and Biotechnology (CASVAB), University of Balochistan, Quetta

${ }^{2}$ World Health Organization (WHO), Sub-Office Quetta, Balochistan, Pakistan

${ }^{3}$ Quaid-i-Azam University, Islamabad, Pakistan
Received: 18 December, 2020

Accepted: 28 December, 2020

Published: 29 December, 2020

*Corresponding author: Asad Khan, PhD, Scholar Pharmacy Practice, Quaid-i-Azam University, Islamabad, Pakistan, Tel: 00923337886837;

E-mail: Assad.pharmacist@gmail.com

Keywords: Coronavirus; COVID-19; Pakistan; MERSCoV; SARS-CoV; Wuhan

https://www.peertechz.com

\section{Check for updates}

\section{Abstract \\ Background: Coronavirus Disease 2019 (COVID-19) continues to spread all around the world, affecting 212 countries that originated from Wuhan, China. In Pakistan, spread of COVID-19 infection is experienced at exponential rate. Until 11 thMay, 2020, total 4,235,237 COVID-19 cases with 285,946 mortalities and 2,430,202 active cases have been reported globally.}

Objective: This study aims to find the rapid increase in figure constrained the nations to initiate various steps to cope with the COVID-19 pandemic.

Methods: In this retrospective analysis, Early Situation of COVID-19 in Pakistan, Spot mapping, Demographic Display, Screening and Surveillance, Health Facilities, Fiscal Support and Exponential growth were included. Data for this study were obtained mainly from COVID-19 dashboard Pakistan up to $9^{\text {th }}$ May, 2020,and world meters until $11^{\text {th }}$ May, 2020

Results: In Pakistan, highest cases appeared in Sindh Province $\mathrm{N}=10,771$. Least cases appeared in $>80$ age group (0.62\%) while most cases appeared in age group ranging between $30-39$ with $16.73 \%$ in male and in female $4.83 \%$ in age group ranging between $20-29$. In Pakistan, the reported case fatality rate (CFR) was $2.2 \%$ while recovery rate was $27.2 \%$, as of $9^{\text {th } M a y, ~} 2020$.

Conculsion: Pakistan is experiences a huge increase in number of COVID-19 cases within a brief period of time despite the fact that Pakistan has shown its efforts by taking various steps as preventive measures for the containment of this pandemic. Furthermore, strengthening of health sector by devising new strategies and hiring of expert professionals scientists will be pivotal to cope with COVID-19 pandemic.

\section{Introduction}

The 2019 novel Coronavirus (2019-nCoV) renamed by the International Committee on Taxonomy of Viruses (ICTV) as Severe Acute Respiratory Syndrome Coronavirus 2 (SARSCoV-2) causes Coronavirus Disease 2019 (COVID-19) [1]. The outbreak of SARS-CoV-2 emerged from Wuhan, China and spread across the world rapidly, affecting more than 209 countries including Pakistan [2]. On $11^{\text {th } M a r c h, ~ 2020, ~ W o r l d ~}$ Health Organization (WHO) declared COVID-19 a global pandemic [3].
The COVID-19 outbreak was experienced for the first time in the bordering countries of Pakistan including China, the epicenter for the disease. An increase in the number of cases at exponential rate has been observed in many countries and Pakistan has both trade and travel with Iran and China which will put Pakistan at greater risk due to the increased influx of travelers, as the virus is already imported to Pakistan through such travelers. Meanwhile, in the West, the highest number of mortalities was recorded in Italy followed by Iran in North $[4,5]$.

On February 26, 2020, Ministry of Health, government 
of Pakistan confirmed its first case of COVID-19 in Karachi, Sindh Province and Federal Ministry of Health confirmed another case in Islamabad on the same day [6]. The number of COVID-19 cases increased rapidly in Pakistan within 2 months, reaching to the 16,473 cases till the end of April month. Such rapid increase of COVID-19 cases in Pakistan needs an effective action plan and managed to contain the current outbreak and further spread of COVID-19. The Ministry of National Health Services, Regulation \& Coordination Pakistan issued the National Action Plan for Coronavirus Disease (COVID-19) on 12 February, 2020, aiming to develop National Preparedness \& Response Plan for COVID-19 and policy framework for federal, provincial and regional stakeholders to build their capacity for prevention, detection and response to COVID-19 pandemic in Pakistan. The plan also includes ensuring effective response timely and efficiently towards current and future respiratory pathogens including COVID-19. Strengthening country and community emergency response will contain the national, regional and local outbreaks influencing population's health and to minimize the disease burden that has its impact on the country's economy [7].

Until now, the government of Pakistan took various steps for the containment of COVID-19 outbreak. This study aimed to analyze the exponential rate of COVID-19 cases and highlight the various steps taken by federal and provincial government including screenings of travelers at all points of entry to the country, to strengthen surveillance system, nominating hospitals \& quarantine centers, expanding molecular testing facilities and fiscal support.

\section{Methods}

In this retrospective analysis, we keenly examine literature ranging from February, 2020 to April, 2020, using PubMed, Embase, Web of Science and Google Scholar to sort out important findings regarding the Outbreak \& Early Situation of Coronavirus Disease 2019 (COVID-19) in Pakistan, where our foremost concerns included early situation in Pakistan along with screening and surveillance as well as exponential rise of COVID-19 cases in the country.

\section{Early situation of COVID-19 in Pakistan}

The COVID-19 cases in Pakistan appeared to have increased during the month of April and May. On $9^{\text {th }}$ May, 2020, the official data reported 28,736 confirmed cases with 636 mortalities, followed by 7,809 recoveries. Highest cases appeared in Sindh Province $(\mathrm{N}=10,771)$, followed by Punjab $(\mathrm{N}=10,471)$, Khyber Pakhtunkhwa (KPK) (N=4,509), Balochistan $(\mathrm{N}=1,876)$, Islamabad (ICT) $(\mathrm{N}=609)$, Gilgit Baltistan $(\mathrm{G}-\mathrm{B})(\mathrm{N}=421)$ and $(\mathrm{N}=79)$ confirmed cases in Azad Jammu \& Kashmir (AJK). Mortalities occurred in Pakistan until 9 May, 2020, were 636 with the highest figure in KPK province $(\mathrm{N}=234)$, followed by Punjab ( $\mathrm{N}=191)$, Sindh $(\mathrm{N}=180)$, Balochistan $(\mathrm{N}=24)$, Islamabad $(\mathrm{N}=4)$ and Gilgit Baltistan $(\mathrm{N}=3)$. The total 7,809 patients have been recovered in Pakistan with a negative lab results as per WHO guidelines, after the positive COVID-19 confirmed tests. Among these recoveries, the highest recovery figure was reported in Punjab $(\mathrm{N}=4,131)$, followed by Sindh $(\mathrm{N}=1,940)$,
KPK (N=1,086), Gilgit Baltistan ( $\mathrm{N}=298)$, Balochiatn $(\mathrm{N}=222)$, Islamabad $(\mathrm{N}=72)$ and $\mathrm{AJK}(\mathrm{N}=60)$. The number of active cases (still positive cases) in Pakistan until $9^{\text {th }}$ May, 2020, are 20,291 of which $(\mathrm{N}=8,651)$ in Sindh, $(\mathrm{N}=6,149)$ in Punjab, $(\mathrm{N}=3,189)$ in $\mathrm{KPK},(\mathrm{N}=1,630)$ in Balochistan, $(\mathrm{N}=533)$ in Islamabad, $(\mathrm{N}=120)$ in Gilgit Baltistan and ( $\mathrm{N}=19)$ active cases in AJK as shown in Table 1 . The case fatality rate (CFR) in Pakistan is $2.2 \%$, while recovery rate is $27.2 \%$, as of 9 May, 2020 [8].

The distribution of COVID-19 cases on spot map shows the geographical display of COVID-19 outbreak and cases in Pakistan. Cities in Provinces/regions with highest, moderate and lowest cases have been shown with legends in Figure 1. The major cities (Karachi, Lahore, Quetta and Peshawar) are the cities with the highest number of reported cases in each province [8].

\begin{tabular}{|c|c|c|c|c|c|}
\hline \multicolumn{5}{|c|}{ Table 1: The current figures and distribution of COVID-19 cases in Pakistan. } \\
\hline \multicolumn{5}{|c|}{ Distribution of COVID-19 Cases in Pakistan until 9 May 2020 } \\
\hline Provinces/Regions & Total \# of Cases & Deaths & Recoveries & Total Active Cases \\
\hline AJK & 79 & 0 & 60 & 19 \\
\hline Balochistan & 1,876 & 24 & 222 & 1,630 \\
\hline G-B & 421 & 3 & 298 & 120 \\
\hline Islamabad & 609 & 4 & 72 & 533 \\
\hline KPK & 4,509 & 234 & 1,086 & 3,189 \\
\hline Punjab & 10,471 & 191 & 4,131 & 6,149 \\
\hline Sindh & 10,771 & 180 & 1,940 & 8,651 \\
\hline
\end{tabular}

The demographic display of COVID-19 in Pakistan shows the proportion of population infected with COVID-19, the least cases $(0.62 \%)$ have been reported in $>80$ age group while most cases appeared to be in proportion of population ranging between $30-39$ age group with $16.73 \%$ in male and $4.83 \%$ in female ranging between 20-29 age group as shown in Figure $2[8]$.

\section{Results}

\section{Screening and surveillance}

World Health Organization (WHO) supported government of Pakistan in establishing preparedness and response to COVID-19, prioritizing screening of all travelers at entry points to the country. Screening is being carried out at airports in Islamabad, Karachi, Lahore, Sialkot, Peshawar and Quetta for international travelers. Screening points have also been established at ground-crossing entrance points, i.e. Chaman and Taftan, bordering to Afghanistan and Islamic Republic of Iran [9]. At point of entry, according to National Guidelines COVID-19 \& PPEs Pakistan, the screening area must be sterile where passengers are screened. The screening includes body temperature and past history of the passenger with fever as well as clinical symptoms suggestive for COVID-19 disease [10].

Furthermore, WHO also took measures to support Pakistan by providing trainings to the health care providers and has facilitated to enhance their capacity for preparedness and 


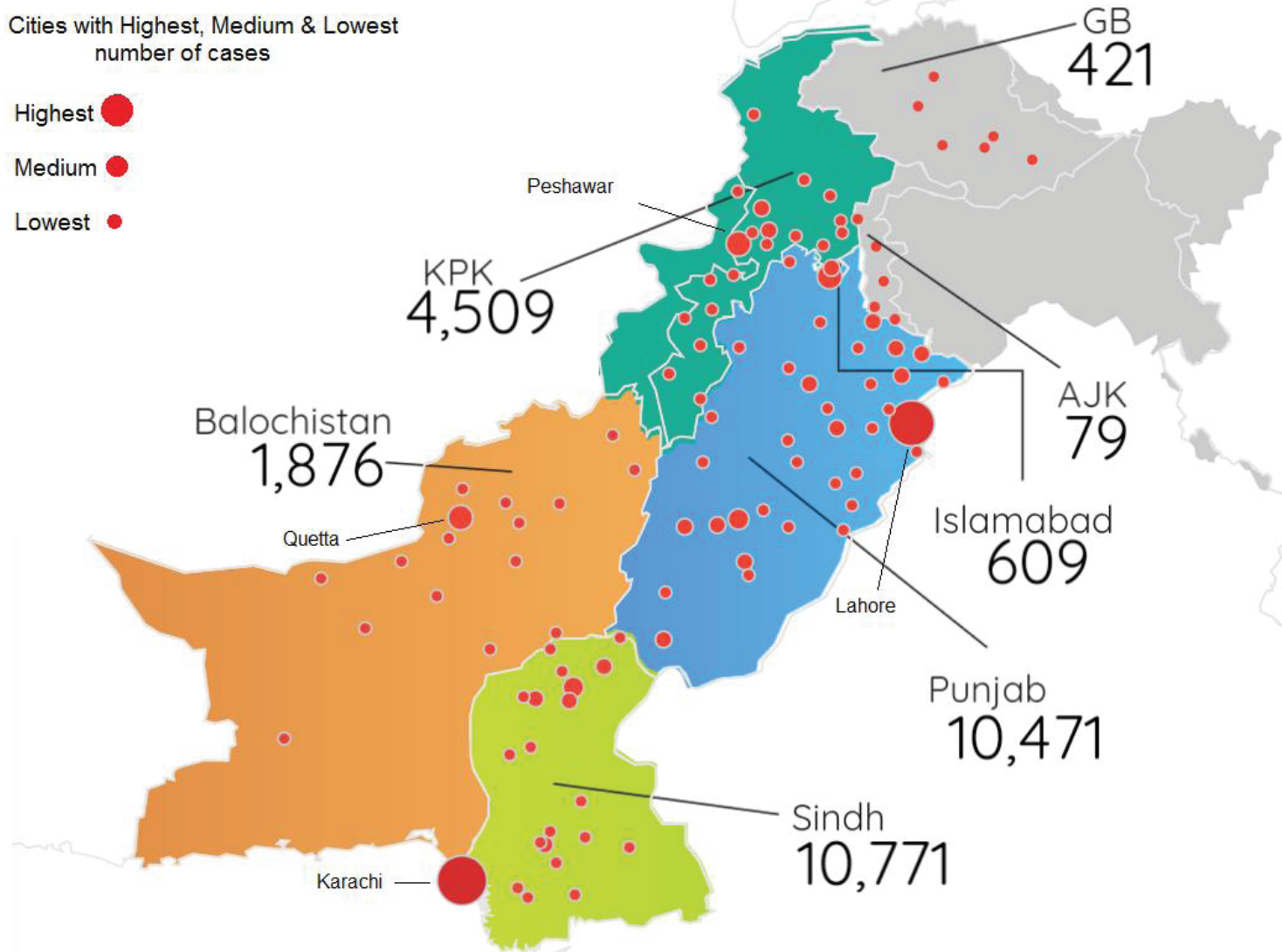

Total confirmed cases $(28,736)$ in Pakistan till 9 May, 2020

Figure 1: Shows the Spot Mapping of COVID-19 cases in Pakistan until 9th May, 2020. (Source: COVID-19 Dashboard, Pakistan.

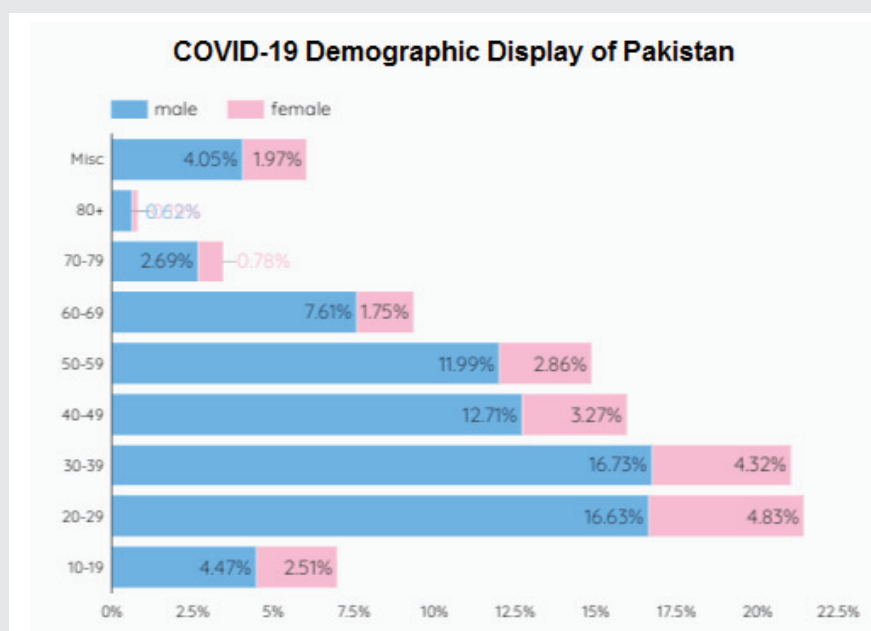

Figure 2: Shows the demographic display of COVID-19 in Pakistan. Source: COVID-19 Dashboard, Pakistan.

response. These trainings aimed to train health care providers on case definition for suspected and confirmed cases, contact tracing, case management, distribution of Personal Protective Equipment (PPE) at health facilities as well as at entry points for managing suspected and confirmed cases, infection, prevention and control measures, triggering Rapid Response
Teams (RRTs) and distribution of Information Education and Communications (IEC) materials to promote awareness in general public about COVID-19, which will prevent and counter the spread of misinformation and rumors. Moreover, WHO aimed to bolster the surveillance system, ensuring timely investigation of suspected and confirmed cases as per the set international standards [9]. Initiation of contact tracing and monitoring is implemented for the close contacts of confirmed cases have been listed and regular follow up is being conducted by Emergency Operating Centers (EOC) across the country [5].

\section{Government of pakistan mitigation strategies against COVID-19}

Government of Pakistan has been taking various steps to curb COVID-19 pandemic since the outbreak. The first confirmed COVID-19 case in Pakistan with a travel history, suggested the importation of virus into the country which let Pakistan to start close monitoring. Meanwhile, the National Institute of Health (NIH) Pakistan, formulated protocols about detection, prevention and transmission of COVID-19. Uniform mitigation strategies were implemented across Pakistan, following national and international guidelines including, early case detection, tracing and tracking of contacts, Risk communication, Dissemination of basic practices to the masses 
to avoid transmission, Social Distancing, Quarantine/Isolation and Proper case management [11].

\section{Health facilities in Pakistan against COVID-19}

The government of Pakistan established different health facilities to cope with COVID-19 including nominated hospitals, quarantine facilities and isolation wards at hospitals. The total 35 hospitals have been designated across the country, of which Balochistan ( $\mathrm{N}=10)$, KPK $(\mathrm{N}=7)$, Punjab $(\mathrm{N}=6)$, Sindh $(\mathrm{N}=4)$, $\mathrm{G}-\mathrm{B}(\mathrm{N}=4), \mathrm{AJK}(\mathrm{N}=3)$ and $(\mathrm{N}=1)$ in Islamabad [12].

Need based assessment of equipment was expected from hospitals to be conducted, securing the availability and provision of Personal Protective Equipment (PPE) and other necessary apparatus. These assessments include availability of Personal Protective Equipment (PPE), ventilators, anti-viral medicines and complete supportive treatment. Infection Prevention \& Control (IPC) measures were implemented at designated hospitals with the trained IPC team and a focal person to ensure the IPC measures being implanted and imbedded. IPC guidelines/ SOPs have been drafted for waste management, disinfection and environmental decontamination. In major cities, hospitals and laboratories are designated for the collection of samples from suspected cases following the proper standards including the Personal Protective Equipment (PPE), lab reagents for safe collection, packing, storage and transportation of samples from the collection site to the Reference Lab. The National Institute of Health (NIH) is nominated to be the national referral center for diagnosis and extension of testing facilities have been ensured at Karachi, Quetta, Gilgit, Peshawar, Lahore and Multan/Bahawalpur. Laboratories set up are also being prepared in other locations but the mobile testing laboratory will be deployed at Taftan, facilitated by experts [5].

Designated quarantine facilities are established in provinces followed by the trained and equipped emergency Rapid Response Teams (RRTs). Province wise quarantine facilities include 350 bedded $(\mathrm{N}=2)$ facilities in Islamabad, 5,897 bedded $(\mathrm{N}=10)$ facilities in Balochistan, 2,760 ( $\mathrm{N}=52)$ in $\mathrm{KPK}, 10,948$ $(\mathrm{N}=6)$ in Punjab, 2,100 $(\mathrm{N}=2)$ in Sindh, $530(\mathrm{~N}=4)$ in AJK and 972 ( $\mathrm{N}=63$ facilities) in Gilgit Baltistan [13].

Rapid and accurate detection of viruses is vital to control infection sources and prevent the progression. Advancement in medical diagnosis and approaches in nucleic acid detection have become the reliable equipment for viral detection, of which, the Polymerase Chain Reaction (PCR) method is considered as the 'gold standard' but real-time, reverse transcriptase-PCR (rtPCR) is one of the todays attention for SARS-CoV -2 detection, due to its specificity and simple qualitative assay $[14,15]$.

Authorities in Pakistan have established and nominated labs in different cities across the country installing rt-PCR facilities. Initially, total 15 labs were fully functional in Pakistan but the existing number of laboratories for Coronavirus testing have been increased to 57 including $(\mathrm{N}=4)$ in Islamabad, $(\mathrm{N}=18)$ in Punjab, $(\mathrm{N}=9)$ in Sindh, $(\mathrm{N}=6)$ in $\mathrm{KPK},(\mathrm{N}=2)$ in Balochistan with one Mobile diagnostic facility at Taftan, $(\mathrm{N}=3)$ in $\mathrm{AJK}$, $(\mathrm{N}=2)$ in $\mathrm{G}-\mathrm{B}$ and $(\mathrm{N}=12)$ laboratories in hospitals under Armed
Forces [16]. The increased in a number of labs aimed to provide diagnostic facilities across Pakistan, as since the outbreak, only 15000 tests were conducted for COVID-19 but has now expanded to 900,000 testing capacity [3].

\section{Exponential rate of COVID-19 in Pakistan}

The disease progression data of COVID-19 in Pakistan are observed and issued by the National Institute of Health (NIH) through live dashboard [8], presents an unusual trend from the first reported case. Until 12 March, 2020, only 21 cases were reported and afterwards constant increase in the number of cases was observed in all regions of Pakistan. Confirmed cases crossed the figure of 500 in the third week of March, 2020, followed by 1000 cases in the next two days [17]. In the month of April, 2020, figure of confirmed cases was reported in thousands, as on 11 April, 2020, the figure was reported to be 5,038. Exponential rate of COVID-19 cases (data) of April until $9^{\text {th }}$ May, 2020 has been plotted in graph, as confirmed cases in March, 2020 were $(\mathrm{N}=2,039)$, in the month of April, 2020, $(\mathrm{N}=16,473)$ and until $9^{\text {th }}$ May, the cases reached to 28,736 , as shown in Figure 3. The first 50 days data of confirmed cases were analyzed and the trend was observed using MATLAB, forecasted that figure will surge in upcoming days. Calculations for disease progression in the upcoming 80 days forecasted that Pakistan will be having positive cases in between the range of $20,240-456,500$, subject to the unusual pattern [18].

\section{Fiscal support by government of Pakistan}

On March 24, 2020, the government of Pakistan announced relief package worth 1.2 trillion PKR, including 100 billion PKR for financial support to SMEs, cash disbursements of PKR 75 billion to daily wage workers, PKR 150 billion for low-income families, PKR 100 billion for tax refunds to the export industry, PKR 15 billion support for health and food supplies, PKR 110 billion for electricity bill payments relief, PKR 70 billion for relief in fuel prices, PKR 100 billion for an emergency contingency fund and PKR 25 billion for the purchase of necessary equipment to deal with the pandemic by National Disaster Management Authority (NDMA). Fiscal measures are also announced by Provincial governments, consisting of tax reliefs, cash grants for lower-income households and additional health spending. Government of Sindh announced PKR 1.5 billion ration distribution programs for the low-

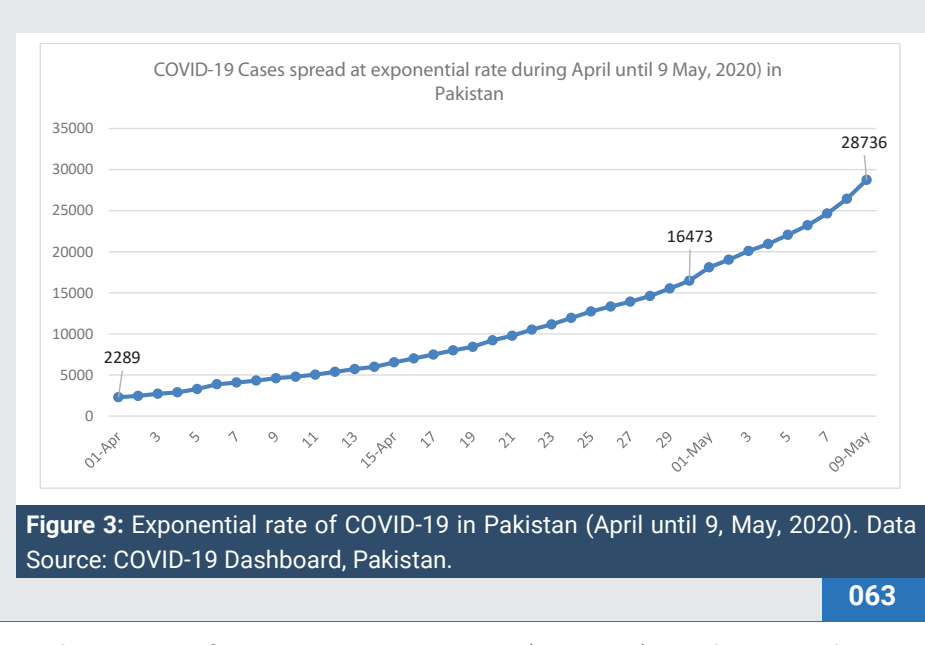

Citation: Achakzai SK, Bugti A, Samad A, khan JA, Khan A, et al. (2020) Outbreak \& Early Situation of Coronavirus Disease 2019 (COVID-19) in Pakistan. Arch Nurs Pract Care 6(1): 060-065. DOI: https://dx.doi.org/10.17352/anpc.000052 
income households as well as cash grant while the government of Punjab announced PKR 18 billion tax relief package and cash grants program [19].

\section{Discussion}

Emergence of COVID-19 from Wuhan city, China has affected 212 countries across the world including developed nations and Pakistan. Reported data suggest that the exponential rise in COVID-19 cases will let Pakistan to be the next country to further spread and fatalities [20]. When compared with developed countries such as the USA and Italy, Pakistan, being a developing nation and under economic crises still needs to strengthen its health sector, as these developed nations have also failed to contain the transmission of the virus due to late actions as well as decisions [21].

Pakistan has shown increased in COVID-19 cases during the month of April, as it has reported 28,736 confirmed cases until $9^{\text {th }}$ May, 2020, of which highest cases are reported from Sindh Province followed by Punjab. Least number of cases appeared in $>80$ age group while the demographic ratio of male was reported as $16.73 \%$ and $4.83 \%$ in female. In the month of March, 2020, the reported cases were 2,039 while in April, 2020, the cases of COVID-19 in Pakistan spread at an exponential rate reporting 16,473 cases. The figure also increased reporting 28,736 COVID-19 cases until $9^{\text {th }}$ May, 2020.

When compared to Saudi Arabia, the health ministry of Saudi Arabia has provided facilities by designating $\mathrm{N}=\mathbf{2 5}$ hospitals for COVID-19-infected patients with 80,000 bedded capacities as well as 8,000 Intensive Care Unit (ICU) and an additional 2,200 beds allocated for isolation of suspected and quarantined cases [22]. In Pakistan, the number of hospitals designated for COVID-19 is $\mathrm{N}=35$ with a less bedded capacity, shows that enough health facilities have been provided by the health ministry of Saudi Arabia. Furthermore, quarantine facilities in Pakistan were N=139 with 23,557 beds shows that these facilities are enough to deal with COVID-19 suspected cases.

Due to low standard of health care facilities, social and political structure, the government of Pakistan still need to take actions to cope with COVID-19 and federal as well as provincial health ministries need to work more by devising further strategies on preventive measures to avoid the spread of Coronavirus disease which will lead the country towards the future disaster [20], as Pakistan has limited resources and with support of international funding and WHO, the country is further expanding and nominating the number of hospitals, quarantine centers, diagnostic testing laboratories and providing necessary equipment.

Moreover, Pakistan also shares borders with China and Iran (the epicenters of Coronavirus) and has considerable transport to and from these countries. Even though, COVID-19 spreads as similar to Severe Acute Respiratory Syndrome (SARS) and Middle East Respiratory Syndrome (MERS), revealing lower mortality rate [23], but rapid diagnostic and quarantine facilities with integrated interventions will greatly affect the future trends of the COVID-19 disease in Pakistan. Flow of travelers between bordering countries, responsible for the spread of the disease further needs research and advanced strategies to bring more accurate and specific forecasts.

In Pakistan, hiring of professionals scientists to perform diagnostic tests, such as reverse transcriptase Polymerase Chain Reaction (rt-PCR), more screening facilities, enforcing strict preventive measures (social and physical distancing, usage of face masks and sanitizers, lock down strategy and general public awareness through Mobilization) will prevent the spread of COVID-19 at exponential rate in country, however, prompt response and timely decisions of Pakistan government will be effective to prevent further transmission of COVID-19.

\section{Conclusion}

Pakistan should promptly response towards COVID-19 pandemic, as it is challenge for medical community which reveals the flaws in managing viral diseases and reminds us that communicable diseases cannot be dealt without sufficient resources. The present situation of coronavirus in Pakistan enables the authorities to assess their capabilities, organizing resources in timely manner and to analyze data for future forecasts.

\section{Authorship contributions}

Concept \& Study Design (Dr. Anwar Bugti, Asad Khan, Farmanullah \&Dr. Abdul Samad) Writing (Safiullah Khan Achakzai and Naveed Ul Haq) \& Analysis (Dr. Jawad Ahmed Khan and Asad Khan).

\section{References}

1. Huang C, Wang Y, Li X, Ren L, Zhao J, et al. (2020) Clinical features of patients infected with 2019 novel coronavirus in Wuhan, China. Lancet 395: 497-506, Link: https://bit.ly/38DWHbh

2. Jin $Y$, Yang $H$, Ji W, Wu W, Chen S, et al. (2020) Virology, Epidemiology Pathogenesis, and Control of COVID-19. Viruses 12: 372. Link: https://bit.ly/3o04Pta

3. Waris A, Atta UK, Ali M, Asmat A, Baset A (2020) COVID-19 outbreak: current scenario of Pakistan. New Microbes \& New Infections 35: 100681.Link: https://bit.ly/2Kvytbd

4. Saqlain M, Munir MM, Ahmed A, Tahir AH, Kamran S (2020) Is Pakistan prepared to tackle the coronavirus epidemic? Drugs Ther Perspect 1-2. Link: https://bit.ly/38J0qEg

5. National Action Plan for Corona virus disease (COVID-19) Pakistan. Link https://bit.ly/37PkoOy

6. Ali I (2020) Pakistan confirms first two cases of coronavirus, govt says "no need to panic". Link: https://bit.ly/34R6mKu

7. National action plan for preparedness \& response to Corona virus disease (Covid-19) Pakistan. Link: https://bit.ly/3pnqQC8

8. COVID-19 dashboard, the Ministry of National Health Services. Regulation and coordination. Link: https://bit.ly/38xGGDq

9. WHO EMRO (2020) WHO extends support to Pakistan as it confirms its first two cases of COVID-19. Link: https://bit.ly/3pphwOn

10. National Guidelines COVID-19 \& PPEs. Guidance on Rational Selection \& Use of Personal Protective Equipment. Link: https://bit.ly/3pqZXNR 
11. National institute of health $(\mathrm{NIH})(2020)$ Advisory on Mitigation Strategies COVID-19. Link: https://bit.ly/37SGccf

12. The Ministry of National Health Services. Regulation and coordination. Link: https://bit.ly/3aO2WMe

13. The Ministry of National Health Services. Regulation and coordination. Link: https://bit.ly/3mWTcBE

14. Shen M, Zhou Y, Ye J, AL-maskri AA, Kang Y, et al. (2020) Recent advances and perspectives of nucleic acid detection for coronavirus. J Pharm Anal 10: 97-101. Link: https://bit.ly/3mU6QW4

15. Wan Z, Zhang Y, He Z, Liu J, Lan K, et al. (2016) A melting curve-based multiplex RTqPCR assay for simultaneous detection of four human coronaviruses. Int $J$ Mol Sci 17: E1880. Link: https://bit.ly/2JrwcNC

16. The Ministry of National Health Services. Regulation and coordination. Link: https://bit.ly/38CLyHv

17. Sohail K (2020) Corona might affect 50-000 in Pakistan. Link: https://bit.ly/3nT4sR3
18. Malik SA, Javed A (2020) Forecasting Unusual Trend of COVID-19 Progression in Pakistan. Link: https://bit.ly/3rwoH9e

19. Policy responses to COVID-19. International Monetary Fund. Key Policy Responses as of April 23, 2020. Link: https://bit.ly/3rx1UKm

20. Saqlain M, Munir MM, Ahmed A, Tahir AH, Kamran S (2020) Is Pakistan prepared to tackle the coronavirus epidemic?. Drugs Ther Perspect 1-2. Link: https://bit.ly/37UKnUW

21. Yousaf M, Zahir S, Riaz M, Hussain SM, Shah K (2020) Statistical Analysis of Forecasting COVID-19 for Upcoming Month in Pakistan. Chaos Solitons Fractals 138: 10992. Link: https://bit.ly/3rrcYbY

22. Saudi Center for Disease prevention and Control. Novel Corona Virus (2019-nCoV) Infection Guidelines V1.2. Kingdom of Saudi Arabia: Saudi Center for Disease Prevention and Control Ministry of Health; March, 2020. Link: https://bit.ly/3mVGt2d

23. Sahin AR, Erdogan A, Mutlu Agaoglu P, Dineri Y, Cakirci AY, et al. (2020) 2019 Novel Coronavirus (COVID-19) Outbreak: A Review of the Current Literature. EJMO 4: 1-7. Link: https://bit.ly/34OVYTh

\section{Discover a bigger Impact and Visibility of your article publication with} Peertechz Publications

\section{Highlights}

* Signatory publisher of ORCID

* Signatory Publisher of DORA (San Francisco Declaration on Research Assessment)

* Articles archived in worlds' renowned service providers such as Portico, CNKI, AGRIS, TDNet, Base (Bielefeld University Library), CrossRef, Scilit, J-Gate etc.

* Journals indexed in ICMJE, SHERPA/ROMEO, Google Scholar etc.

* OAI-PMH (Open Archives Initiative Protocol for Metadata Harvesting)

* Dedicated Editorial Board for every journal

* Accurate and rapid peer-review process

* Increased citations of published articles through promotions

* Reduced timeline for article publication

Submit your articles and experience a new surge in publication services (https://www.peertechz.com/submission).

Peertechz journals wishes everlasting success in your every endeavours.

Copyright: ( 2020 Achakzai SK, et al. This is an open-access article distributed under the terms of the Creative Commons Attribution License, which permits unrestricted use, distribution, and reproduction in any medium, provided the original author and source are credited.

Citation: Achakzai SK, Bugti A, Samad A, khan JA, Khan A, et al. (2020) Outbreak \& Early Situation of Coronavirus Disease 2019 (COVID-19) in Pakistan. Arch Nurs Pract Care 6(1): 060-065. DOI: https://dx.doi.org/10.17352/anpc.000052 